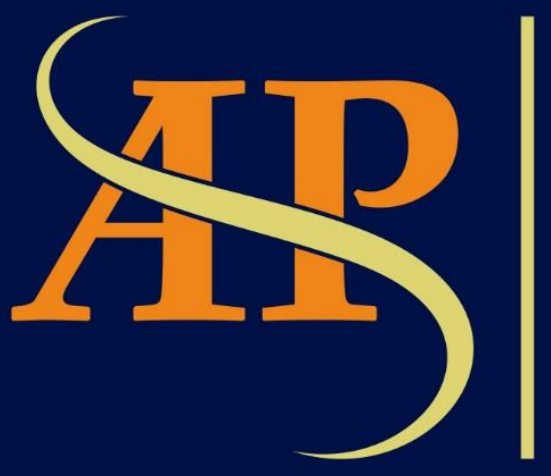

JURNAL

ASIA PACIFIC STUDIES

Journal of International Relations Study Program Faculty of Social and Political Sciences Universitas Kristen Indonesia

Volume 3 | Number 2 | July - December 2019 


\title{
REASONING CRIMINAL - IMPLIKASI LIMBAH HASIL OPERASIONAL KAPAL TERHADAP EKOSISTEM LAUT DI SELAT MALAKA
}

\author{
${ }^{1}$ Verdinand Robertua, ${ }^{2}$ Bryan Libertho Karyoprawiro, ${ }^{3}$ Gloria Nathalia Hana Dhena \\ ${ }^{123}$ Hubungan Internasional, Fakultas Ilmu Sosial dan Ilmu Politik, Universitas Kristen Indonesia, Jl. Mayjen \\ Sutoyo No. 2, Cawang, Jakarta Timur, Daerah Khusus Ibukota Jakarta, 13630, Indonesia \\ ${ }^{1}$ verdinand.robertua@uki.ac.id, ${ }^{2}$ bryanlibertho@gmail.com, ${ }^{3}$ minervalizon@gmail.com
}

\begin{abstract}
The Malacca Strait has always been the most strategic world trade route. The majority of foreign vessels crossing the Malacca Strait transit at the Port of Singapore. The potential of environmental pollution in the Malacca Strait area is also enormous, especially the pollution from vessel waste resulting from the operational activities of vessels in the form of liquid waste and garbage dumped in vain and the washing of vessels. The operational events of foreign ships in violation of international treaties and Indonesian law often occur in Indonesian coastal areas. Indonesian waters were victims of foreign vessels who carried out illegal activities to reduce operational costs and avoid sanctions from the port authorities. Singapore's regulation required that every ship to be anchored in Singapore's port clean from waste. Singapore's laws encourage illegal ship laundering and waste disposal in the Straits of Malacca. The supervision against each vessel that crosses and violates the rules and the establishment of a particular zone of vessel cleaning in the Straits of Malacca can reduce environmental damage. This research used qualitative methods using rational choice and institutional approach in environmental view to see how ecological problems caused by vessel waste occurred and cause cross border problems threatening ecosystems in the Straits of Malacca, especially the Indonesian water area. Data used in the form of qualitative data are collected through document analysis, interviews, focus group discussions, and observations.
\end{abstract}

Keywords: Shipping waste, Malacca Strait, Marine Pollution, Rational Choice.

\begin{abstract}
Abstrak
Selat Malaka adalah rute perdagangan dunia yang sangat strategis. Mayoritas kapal asing menyeberangi Selat Malaka transit di pelabuhan Singapura. Potensi pencemaran lingkungan di daerah Selat Malaka juga sangat besar, terutama pencemaran dari limbah kapal yang dihasilkan dari kegiatan operasional kapal dalam bentuk limbah cair dan sampah yang dibuang dengan sembarangan dan pencucian kapal secara ilegal. Kegiatan operasional kapal asing yang melanggar perjanjian internasional dan hukum Indonesia sering terjadi di wilayah pesisir Indonesia. Perairan Indonesia adalah korban dari kapal asing yang melakukan kegiatan ilegal untuk mengurangi biaya operasional dan menghindari sanksi dari otoritas pelabuhan dan peraturan Singapura yang mengharuskan setiap kapal untuk berlabuh di Pelabuhan Singapura itu bersih dari limbah. Peraturan yang dibuat oleh pemerintah Singapura mendorong pembuangan limbah ilegal di Selat Malaka. Pengawasan dan hukuman berat terhadap setiap kapal yang melintasi dan melanggar aturan, serta pembentukan zona khusus pembersihan kapal di Selat Malaka dapat mengurangi kerusakan lingkungan di Selat Malaka. Penelitian ini menggunakan metode kualitatif menggunakan pilihan rasional dan pendekatan kelembagaan dalam pandangan lingkungan hidup untuk melihat bagaimana masalah lingkungan yang disebabkan oleh limbah kapal terjadi dan menyebabkan masalah lintas batas yang mengancam ekosistem Selat Malaka, terutama di wilayah air Indonesia. Data yang digunakan dalam bentuk data kualitatif dikumpulkan melalui kajian dokumen, wawancara, focus group discussion, dan pengamatan yang dilakukan.
\end{abstract}

Kata Kunci: Limbah Kapal, Selat Malaka, Polusi Laut, Pilihan Rasional 


\section{Pendahuluan}

\subsection{Latar Belakang}

Laut selalu menjadi fokus utama bagi kehidupan umat manusia. Secara historis, kontribusi laut terhadap perkembangan manusia dapat dilihat dari sedikitnya empat atribut yang saling terkait dan saling bergantung. Laut menjadi penting karena sumber daya yang terkandung di dalamnya, kegunaannya sebagai alat transportasi dan perdagangan, dan menjadi alat pertukaran informasi (Till 2009). Posisi Selat Malaka merupakan jalur laut terpenting di Asia Tenggara. Kawasan sepanjang 550 mil ini merupakan salah satu jalur laut sempit namun dilalui ribuan kapal dari berbagai negara setiap tahunnya. Selat Malaka menghubungkan sub-kontinen India bagian timur dengan Asia Tenggara serta menjembatani Eropa (Sindonews, 2019). Meskipun tidak termasuk dalam kategori selat internasional, Selat Malaka diakui dunia sebagai selat yang digunakan dalam pelayaran internasional (straits used for international navigation) sebagaimana diatur dalam United Nations Convention on Law of the Sea (UNCLOS) 1982.

Kondisi Selat Malaka tidak terlepas dari permasalahan yang ditimbulkan oleh kapalkapal angkutan yang melintasi Selat Malaka dan hendak memasuki wilayah Singapura sebagai pelabuhan transit maupun ship-to-ship transfer. Melalui peraturan Maritime \& Port Authority of Singapore nomor 16 tahun 2008 section 2 ayat D dan E ditegaskan bahwa kapal hanya boleh berlabuh di pelabuhan Singapura apabila kapal dalam kondisi bersih dan sudah memiliki sertifikat dari otoritas pengecekan kebersihan kapal di Singapura.

Peraturan ini menyebabkan banyak kapal yang menuju pelabuhan Singapura melakukan pencucian kapal di Selat Malaka untuk menekan biaya operasional. Mereka juga membuang air sisa pendinginan mesin, air cucian kapal, maupun air yang sengaja dimasukan ke dalam palka kapal untuk menyeimbangkan kapal ke laut, istilah ini disebut dengan ballast water atau air balas (imo.org, 2019). Air balas yang dibuang oleh kapal-kapal ini mengandung minyak serta oli kapal maupun material lain yang tergolong ke dalam limbah B3 atau bahan beracun dan berbahaya yang mengancam lingkungan laut.

Kegiatan ilegal ini dilakukan demi menekan tenaga dan biaya yang harus dikeluarkan serta terhindar dari sanksi pemerintah Singapura. Di dalam hukum pelayaran, setiap kapal harus menyalakan VMS (Vessel Monitoring System) yang dapat memperlihatkan lokasi kapal dan segala muatan serta alur pembersihan kapal itu dicatat dalam logbook yang dicek dan dikontrol di tiap titik turun atau transit kapal oleh petugas pelabuhan. Namun oknum kapal terkadang dengan sengaja mematikan signal VMS dan tidak melakukan pencatatan dalam logbook. Dalam hal ini, Indonesia yang paling dirugikan terhadap tumpahan minyak maupun limbah yang berasal dari kapal yang melintas baik akibat kecelakaan maupun kesengajaan oknum kapal.

Pencemaran lingkungan yang terjadi akibat limbah buangan kapal semakin mengancam perairan Indonesia. Terlebih pada musim utara yang berlangsung dari Oktober hingga Februari ketika angin dan arus laut mengarah ke Kepulauan Riau. Para oknum kapal menganggap otoritas laut Indonesia lemah di dalam penegakan hukum dan mereka dengan sengaja menggunakan dispersan untuk menutupi jejak pencemaran laut.

Dispersan digunakan untuk menghilangkan genangan minyak di atas laut dan mempermudah proses pencucian kapal dan tanki. Kapal biasanya melarutkan dispersan yang tergolong ke dalam bahan berbahaya dan beracun untuk membantu menguraikan gumpalan besar minyak menjadi lebih kecil dan menyebar. Oknum kapal juga memiliki sistem perhitungan sendiri terkait pergerakan angin karena muson barat dan muson timur memiliki pengaruh terhadap kegiatan pencemaran lingkungan tersebut. Pola pergerakan partikel minyak untuk menggerakan minyak di dasar permukaan laut digerakkan oleh angin dan arus laut. 
Ketika angin mengarah ke Indonesia, banyak insiden pencemaran ekosistem laut dan juga habitat hewan laut yang ada di sekitar kawasan Selat Malaka terancam (Gunadharma, 2019).

Tentunya kondisi fisik dan karakteristik kimia air laut yang sudah tercemar akan mempengaruhi ekosistem dan biota laut di Selat Malaka. Misalnya Pulau Bintan, pulau yang terletak di kawasan Selat Malaka, setidaknya dalam sedasawarsa terakhir, menjadi kewalahan dengan adanya kiriman limbah minyak yang diduga berasal dari kapal tanker berukuran raksasa di Selat Malaka.

Dinas Kelautan dan Perikanan (DKP) Provinsi Kepulauan Riau melaporkan pada tahun 2016 populasi dugong yang hidup di Kepulauan Riau jumlahnya semakin berkurang. Satu di antara penyebabnya adalah pencemaran laut yang terjadi di Selat Malaka. Akibatnya dugong berenang ke luar habitat, tersasar dan terdampar di pantai. Menurut Coremap CTI-LIPI, biota laut lainnya yang wajib dilindungi karena terancam punah di perairan Kabupaten Bintan yaitu pesut, hiu paus, kuda laut, kima, lola, teripang dan ikan napoleon. Selain itu, pulau-pulau di Kabupaten Bintan juga menjadi lokasi sebaran habitat bagi 3 dari 7 spesies penyu yang ada di dunia, yaitu Penyu Hijau (Chelonia mydas), Penyu Sisik (Eretmochelys imbricata) dan Penyu Lekang (Lepidochelis olivacae).

ASEAN sebagai organisasi regional di Asia Tenggara telah menghasilkan poin-poin serta rekomendasi penting dalam mendorong negara anggota untuk mematuhi dan berkomitmen dalam hukum internasional yang relevan, termasuk menetapkan hukum dan peraturan terkait kelestarian fungsi lingkungan laut, dan meningkatkan harkat hidup nelayan serta masyarakat pesisir. Tumpahan limbah minyak dari kapal merusak ekosistem laut terutama di wilayah ekosistem pesisir yaitu ekosistem terumbu karang, lamun, dan bakau. Ekosistem tersebut merupakan tempat mencari makan bagi organisme laut. Kerusakan pada ekosistem tersebut mengakibatkan kematian organisme laut seperti koral, ikan karang, alga dan lamun serta memutus rantai makanan di laut.

\subsection{Rumusan Masalah}

Lalu lintas kapal yang melewati Selat Malaka semakin padat akibat dari perkembangan ekonomi dunia. Perkembangan lalu lintas kapal menyebabkan peningkatan pencemaran di kawasan Selat Malaka. Banyak kapal melakukan kegiatan dumping dan pencucian kapal secara ilegal. Pencemaran tersebut mengancam ekosistem laut Indonesia terutama di Selat Malaka. Dalam perspektif rational choice, oknum kapal memilih melakukan kegiatan ilegal tersebut di kawasan Indonesia akibat keinginan untuk memenuhi kepentingan bisnis mereka dan lemahnya pengawasan Indonesia di kawasan tersebut (Cote dan Suzette, 2002). Peneliti mengangkat penelitian berjudul "Reasoning Criminal - Implikasi Limbah Hasil Operasional Kapal Terhadap Ekosistem Laut di Selat Malaka".

Berdasarkan uraian pada latar belakang dan rumusan masalah di atas, penulis merumuskan pertanyaan penelitian yang perlu dijawab dalam penelitian ini,

1. Bagaimana pencemaran lingkungan akibat dari pencucian kapal ilegal terjadi di Selat Malaka?

2. Bagaimana implikasi dari pengawasan dan penguatan hukum serta pengaturan zona pencucian kapal terhadap penanggulangan permasalahan lingkungan yang terjadi di Selat Malaka?

\subsection{Tujuan}

Adapun tujuan dari penelitian ini adalah: 
1. Untuk mengetahui bagaimana pencemaran lingkungan yang terjadi di kawasan Selat Malaka,

2. Untuk mengetahui bagaimana implikasi dari pengawasan dan penguatan hukum serta pengaturan zona pencucian kapal terhadap penanggulangan permasalahan lingkungan yang terjadi di Selat Malaka

\section{$1.4 \quad$ Kegunaan}

Adapun manfaat dari penelitian ini adalah:

1. Menambah khasanah pengetahuan bagi kalangan akademisi, intelektual dan masyarakat umum tentang kebijakan dan strategi penanganan pencemaran lingkungan laut serta dinamika yang terjadi di Selat Malaka sebagai jalur perdagangan internasional

2. Menambah wawasan bagi kalangan akademisi, intelektual dan masyarakat umum tentang kebijakan serta strategi Pemerintah Indonesia dalam upaya meningkatkan keamanan lingkungan laut dan upaya penanggulangan kerusakan ekosistem laut

3. Secara praktis, penelitian ini diharapkan dapat menjadi laporan sekaligus juga bahan pertimbangan dan pedoman pengambilan kebijakan Pemerintah Indonesia dalam penanggulangan pencemaran laut serta dalam menyikapi dinamika yang terjadi di Selat Malaka.

\section{Kerangka Pemikiran}

\subsection{Kelembagaan (Institution)}

Teori kelembagaan (institution) dalam teori hijau (green theory) mengkritik perspektif realis mengenai pengutamaan kedaulatan negara dalam sebuah proses pengambilan kebijakan. Teori kelembagaan menyatakan bahwa pengaturan kelembagaan domestik dapat mendorong komitmen suatu negara dalam kebijakan internasional. Kapasitas negara untuk melaksanakan komitmen internasional melibatkan kemampuan untuk memaksakan kerugian pada kelompokkelompok yang memiliki kepentingan berbeda dengan negara. Tujuan perjanjian lingkungan adalah untuk memberikan keuntungan pada kepentingan bersama dan manfaatnya disebarkan kepada masyarakat umum, bukan hanya daerah atau sektor tertentu.

Komitmen negara dalam melakukan perjanjian internasional dapat memberikan dampak yang merugikan bagi industri dan organisasi tertentu. Lembaga-lembaga politik yang memiliki kekuasaan dan kontrol terpusat memiliki kapasitas yang lebih kuat untuk membatasi akses kepentingan kelompok tertentu dan menyediakan keterlibatan yang lebih luas dalam perjanjian lingkungan internasional.

Keputusan pembuatan kebijakan terpusat dapat membatasi peluang kelompok dan organisasi politik yang ingin menolak komitmen dalam perjanjian internasional. Namun, lembaga-lembaga politik konsensual, dengan proses pembuatan kebijakan yang dibagi dan disebarluaskan, dengan banyak partai politik dan kepentingan yang berbeda-beda ke dalam pengambilan keputusan kebijakan luar negeri maupun pelaksanaan perjanjian tersebut akan membuka peluang terjadinya penolakan dan berkurangnya kometmen ratifikasi perjanjian internasional suatu negara. 


\subsection{Rational Choice}

Dalam perspektif rational choice, sebuah tindak pelanggaran aturan hukum atau kriminal dilakukan karena adanya dorongan untuk melakukan tindakan kriminal. Pelaku tersebut telah melihat adanya keuntungan yang mereka dapat dengan melakukan kejahatan atau perilaku kriminal mereka. Pelaku tersebut melakukan kejahatan atau perilaku kriminal jika pilihan-pilihan yang ada di dalam proses kegiatannya berada di waktu yang tepat, berada dalam batasan kemampuan kognitif pelaku, dan ketersediaan informasi-informasi yang dibutuhkan pelaku untuk melakukan kejahatan atau perilaku kriminal mereka. Konsep reasoning criminal merupakan turunan rational choice yang menawarkan basis analisis yang memprediksikan pilihan pelaku kriminal berdasarkan untung rugi yang didapatkan oleh seorang pelaku.

Cote dan Suzette $(2002,291)$ berpendapat bahwa proses pengambilan keputusan pelaku untuk melakukan tindak pelanggaran dibagi ke dalam dua tingkatan utama yaitu: Pertama, pelaku harus memutuskan apakah mereka berniat untuk terlibat dalam sebuah tindak kriminal atau melanggar aturan untuk memuaskan keinginan ataupun kebutuhan mereka. Faktor ini dijelaskan sebagai "initial involvement model". Apakah mereka akan ikut terlibat dalam tindak kriminal atau tidak sangat dipengaruhi oleh proses pembelajaran yang sudah diterima. Termasuk pengalaman mereka dalam tindak kriminal, pengalaman dengan pihak berwajib, kondisi moral dan perilaku mereka, persepsi pribadi, serta tingkatan kemampuan mereka dalam membuat sebuah rencana. Faktor-faktor pembelajaran ini yang mereka dapat dari berbagai latar belakang termasuk pengalaman secara fisik, sosial, maupun secara demografik dalam kehidupan mereka.

Kedua, setelah oknum tersebut memutuskan ingin terlibat dalam sebuah tindak kriminal atau kegiatan melanggar aturan, mereka harus menentukan fokus tindakan mereka atau kejahatan model apa yang akan mereka lakukan. Bentuk tindakan kriminal sangat dipengaruhi oleh keadaan situasional pelaku tersebut dan melewati pertimbangan cost-and-benefit yang akan didapatkan oleh pelaku tersebut. Seperti apakah lokasi tindak kriminal yang mereka lakukan, apakah tindak kriminal tersebut akan diketahui atau tidak, keuntungan apa yang akan mereka dapat, serta hukuman yang mungkin mereka dapat jika melakukan tindakan tersebut. Dalam beberapa pandangan ahli pendekatan rational choice berfokus pada bagaimana tindakan individu atau kelompok dipengaruhi oleh structure-generate-interest dimana struktur yang berada di sekitar agen mendorong agen atau oknum tersebut untuk melakukan kegiatan maupun perilaku kriminal (Satz, Debra, and John Ferejohn 1994, 71-87).

\subsection{Criminal Deterrence}

Criminal Deterrence merupakan sebuah konsep yang berfokus pada bagaimana pencegahan pelanggaran aturan hukum dapat terjadi. Terdapat tiga elemen dalam criminal deterrence yang menjadi sebuah satu kesatuan yaitu probabilitas penangkapan, probabilitas hukuman, dan beratnya hukuman yang diberikan kepada oknum. Dengan meningkatkan baik probabilitas penangkapan, probabilitas hukuman, maupun beratnya hukuman, tingkat kriminalitas dapat dikurangi (Mendes dan Silvia 2004, 59).

Secara konseptual, logika dari criminal deterrence cukup sederhana. Menurut Eide, probabilitas penangkapan dianggap memiliki tingkatan yang paling tinggi dibandingkan dengan beratnya hukuman (Eiede et al. 1994, 263-310). Meningkatkan kepastian atau beratnya hukuman akan mengurangi utilitas yang diharapkan terkait dengan kejahatan. Becker dan Gary menyatakan bahwa kepastian atau probabilitas penangkapan dan beratnya hukuman tergantung pada sikap penjahat terhadap resiko (Becker dan Gary 1968, 169-217). 


\section{Objek dan Metode Penelitian}

Dalam melaksanakan penelitian ini, penulis menggunakan metodologi penelitian kualitatif bukan untuk menghasilkan temuan bersifat numerikal dan data statistik. Dengan menggunakan metode kualitatif, hasil penelitian ini akan didapatkan sebuah narasi yang berasal dari hasil wawancara, pengamatan, maupun hasil penggalian data dari dokumen. Metode penelitian kualitatif merupakan bentuk metode dimana peneliti dalam mengumpulkan dan menganalisis data menjadi bagian dari proses penelitian dengan berpartisipasi menjadi pemberi informasi. Metode kualitatif digunakan agar dapat menjelajahi seluruh sudut penelitian secara menyeluruh serta agar dapat menemukan variable-variabel yang relevan dengan penelitian yang dilakukan dan melihat kejadian nyata yang terjadi secara utuh dan komprehensif. Penelitian ini dilakukan bukan hanya dengan mengumpulkan data tetapi juga merupakan penelitian yang menganalisis dan mengkaji setiap data yang telah dikumpulkan (Corbin dan Strauss, 2009).

Dalam penelitian ini, data - data yang sudah dikumpulkan dikelompokan ke dalam dua kategori yaitu data primer dan data sekunder. Data primer adalah data yang berupa hasil pengumpulan data secara langsung dari seseorang yang berkaitan ataupun dokumen. Data primer di dalam penelitian ini berupa data yang didapatkan dari wawancara dengan Budhi Gunadharma dan M. Saefudin dari Pusat Riset Kelautan Kementrian Kelautan dan Perikanan.

\section{Hasil dan Pembahasan}

Selat Malaka merupakan jalur pelayaran yang penting dan strategis di kawasan IndoPasifik. Ana G. Lopez dalam bukunya International Straits: Concept Classification and Rules of Passage mengungkapkan selat internasional adalah:

"Sebuah wilayah perairan alami yang menjadi tempat perlintasan yang ukurannya tidak lebih luas dari dua kali lebar laut teritorial negara pantai masing - masing, selat internasional memisahkan dua daratan dan menghubungkan antara satu laut lepas sebuah negara pantai dengan laut lepas negara lain atau antara satu Zona Ekonomi Ekslusif (ZEE) dengan ZEE lain dengan laut teritorial negara lain jika memungkinkan, selat internasional menghubungkan perairan pedalaman dari sebuah perairan kepulauan yang digunakan untuk pelayaran internasional."

Selat Malaka dianggap sebagai jantung perdagangan global. Hal ini dibuktikan dengan 60.000 sampai 94.000 kapal melalui Selat Malaka tiap tahunnya. Kapal - kapal tersebut di antaranya membawa 25\% barang dagang dunia, 2/3 Liquefied Natural Gas (LNG) dunia, serta 11 juta barel minyak per hari (detik.com , 2018). Namun, di balik nilai strategis dari segi ekonomi, Selat Malaka juga memiliki permasalahan lingkungan laut lintas batas di Asia Tenggara. Potensi pencemaran Selat Melaka berujung kepada rusaknya ekosistem di Selat Malaka. Pencemaran tersebut bisa terjadi karena adanya tumpahan minyak, baik yang berasal dari kecelakaan kapal seperti kasus Showa Maru pada tahun 1975 maupun buangan air balas dari kapal-kapal yang melintasi Selat Malaka.

Diperkirakan 7.300 ton galon minyak bumi ditumpahkan ke Selat Malaka dan menimbulkan pencemaran besar pada perairan Singapura dan Malaysia serta Indonesia (Thambipilai dan Saravamuttu 1985, 8). Limbah hasil operasional kapal yang melintas mencemari lingkungan laut di Selat Malaka. Perjanjian internasional yang mengatur permasalahan pencemaran lingkungan yang dilakukan oleh kapal adalah Konvensi Internasional untuk Pencegahan Pencemaran dari Kapal atau yang dikenal sebagai MARPOL. 
MARPOL merupakan acuan utama dalam penanganan pencemaran lingkungan yang disebabkan oleh kegiatan operasional kapal maupun kecelakaan kapal yang terjadi di dunia.

Konvensi MARPOL mulai diadopsi organisasi maritim internasional pada 1973 dan sudah menjadi acuan utama dalam penanganan persoalan pencemaran laut akibat dari operasional kapal dan kecelakaan di laut. Konvensi MARPOL memiliki beberapa cakupan yang bertujuan untuk mencegah dan mengurangi potensi pencemaran laut akibat kegiatan operasional kapal maupun kecelakaan di laut. Konvensi MARPOL sudah memiliki enam cakupan teknis terkait permasalahan pencemaran laut dan mencakup kontrol ketat dalam beberapa area teknis terkait (International Marine Organization, 2019).

Dalam permasalahan pencemaran lingkungan lintas batas yang sering terjadi di kawasan Selat Malaka terutama yang terjadi di sekitar kawasan Kepulauan Riau dan habitat dugong di sekitar Pulau Bintan, cakupan konvensi MARPOL annex pertama, kedua, dan kelima dapat menjadi acuan utama dalam penegakan hukum serta pembuatan kebijakan dalam penanggulangan pencemaran lingkungan yang terjadi karena sebagian besar pencemaran lingkungan yang ada di kawasan tersebut berasal dari kegiatan operasional kapal yang berlayar melintasi Selat Malaka.

Dalam annex pertama konvensi MARPOL yang mencakup tentang pencegahan pencemaran dari minyak yang mana di dalam annex pertama ini dijabarkan bagaimana pencegahan pencemaran tersebut dapat dilakukan meliputi langkah-langkah operasional kapal, pencegahan pembuangan minyak, penggunaan lambung ganda, dan juga kegiatan pencucian kapal dan tangki secara mendasar untuk mencegah pencemaran di laut (International Marine Organization, 2019). Di bagian annex kedua konvensi MARPOL, terdapat cakupan pencegahan dan pengendalian pencemaran yang disebabkan oleh zat cair berbahaya dalam jumlah besar.

Annex kedua ini juga mengatur kategori zat cair berbahaya tersebut ke dalam empat kategori cairan berbahaya yang jika dibuang lewat proses pencucian kapal, tangki, maupun proses deballasting atau pembuangan air balas dapat membahayakan sumber daya laut dan kesehatan manusia. Dalam annex ini juga dijelaskan cairan berbahaya apa saja yang dilarang, dikontrol, dan dibebaskan untuk penggunaan pembersihan kapal dan deballasting serta volume cairan yang dapat digunakan dalam proses tersebut (International Marine Organization, 2019).

Annex kelima dalam konvensi MARPOL mencakup upaya pencegahan dan mengurangi jumlah sampah yang dibuang ke laut dari kapal baik secara langsung maupun pembuangan sampah dalam proses operasional kapal, pencucian kapal, maupun tangki kapal. Dalam annex ini lebih berkaitan dengan pembuangan sampah seperti limbah makanan, limbah sisa dari kargo, zat pembersih kapal dan juga bangkai hewan. Cakupan sampah termasuk semua jenis makanan, limbah domestik dan operasional, semua plastik, residu muatan, abu incinerator, minyak goreng, alat tangkap seperti jaring maupun kail, yang dihasilkan selama kapal melakukan kegiatan operasional baik dalam pelayaran maupun kegiatan pembersihan kapal (International Marine Organization, 2019).

MARPOL annex pertama, kedua, dan kelima menjabarkan bagaiamana setiap kegiatan operasional yang dilakukan kapal terutama dalam proses pembersihan kapal harus dilakukan secara baik dan limbah yang dihasilkan dari operasional kapal tidak dibenarkan untuk dibuang secara sembarangan. Cairan maupun sampah yang dihasilkan dari operasional kapal dapat mengancam sumber daya laut serta membahayakan bagi kesehatan manusia. Perjanjian serta instrumen internasional yang mendukung pencegahan pencemaran lingkungan yang dilakukan oleh kapal lewat kegiatan operasionalnya bagi secara legal maupun ilegal telah diatur dalam MARPOL.

Puluhan ribu kapal yang berlayar di Selat Malaka setiap tahunnya, selain kerap kali terjadi kecelakaan tabrakan kapal sehingga minyak tumpah ke perairan, juga diduga terdapat unsur kesengajaan dari pemilik kapal yang melakukan kegiatan dumping dengan membuang 
limbah hasil kegiatan operasional kapal ke laut. Kegiatan pembuangan limbah yang dilakukan oknum kapal dapat dilakukan dengan membuang, menempatkan, dan/atau memasukkan limbah dan/atau bahan dalam jumlah, konsentrasi, waktu dan lokasi tertentu. Limbah buangan kapal dikategorisasikan berdasarkan asal, jumlah total, bentuk, komposisi, sifat (fisik, kimia, biokimia, biologis), toksisitas (kesesuaian, aditif, sinergis, antagonis, dan efek lain dari limbah), presistensi limbah (fisik, kimia, biologis), akumulasi, serta biotransformasi terhadap material biologi dan sedimen. Melalui kategorisasi tersebut, peneliti dapat mengambil sebuah acuan untuk limbah buangan kapal yang dapat di buang ke laut atau tidak sehingga tidak mengancam dan merusak ekosistem lingkungan laut yang ada (International Marine Organization, 2019)

Sebuah penelitian yang dilakukan Razak pada tahun 1989 melaporkan bahwa konsentrasi logam berat di Selat Malaka mengalami kenaikan Mercury $(\mathrm{Hg})$ mencapai 0.013 ppm, lead $(\mathrm{Pb})$ dari 0.035 menjadi $0.060 \mathrm{ppm}$, cadmium $(\mathrm{Cd})$ dari 0,009 menjadi 0,014 ppm, dan Copper $(\mathrm{Cu})$ dari 0,071 menjadi 0,107 ppm (Moosa dan Kasim 1998, 454). Berbagai insiden kecelakaan kapal terjadi di Selat Malaka menyebabkan tumpahan minyak dan zat-zat berbahaya ke dalam air. Tumpahan minyak dan zat-zat yang berbahaya mengakibatkan peningkatan kandungan nitrogen serta zat-zat berbahaya lainya yang dapat memberikan kematian bagi biota laut di Selat Malaka.

Perlindungan lingkungan laut dalam kerangka hukum internasional sebenarnya merupakan implementasi dari The Principle of National Sovereignty and The Freedom of High Sea International Maritime Organization (IMO 1998, 2). Hasil verifikasi lapangan Badan Lingkungan Hidup Provinsi Kepulauan Riau dalam laporan Ditjen PSLB3 KEMENKLHK tahun 2017 menduga limbah minyak maupun berbagai jenis sampah yang berasal dari pembersihan tangki kapal maupun kegiatan operasional lainya dibuang di perairan internasional Selat Malaka (dpr.go.id, 2019). Terlebih melalui peraturan Pemerintah Singapura dalam 'Maritime \& Port Authority of Singapore Nomor 16 Tahun 2008 pasal 2 Ayat D \& E' mengharuskan setiap kapal yang akan melakukan kegiatan operasionalnya di pelabuhan Singapura baik proses berlabuh, transit, maupun proses ship-to-ship transfer di seluruh pelabuhan yang diatur oleh MPA Singapura telah memiliki sertifikat kebersihan yang didapatkan dari proses pengecekan fisik kapal baik badan kapal maupun tangki (MPA Singapore, 2018).

Peraturan ini mengharuskan setiap kapal melakukan pembersihan kapal secara menyeluruh. Ketika kapal-kapal tersebut melakukan pencucian kapal di daerah Singapura, aturan MPA mengharuskan setiap kapal dicuci dan limbah buangannya diangkut oleh perusahaan yang telah memiliki sertifikasi dan standar tertentu. Akibatnya biaya pembersihan kapal di pelabuhan Singapura sangat tinggi, biaya pengangkutan serta aturan pembersihan kapal di pelabuhan Singapura juga sangat ketat dan memakan banyak biaya. Dalam penanganan pencegahan pencemaran lingkungan yang terjadi di Selat Malaka, peran pemerintah Indonesia sangat diperlukan untuk mendukung serta berkomitmen dalam ratifikasi poin-poin peraturan yang ada di MARPOL. Sampai sekarang pemerintah Indonesia sudah meratifikasi hampir seluruh poin di dalam annex yang ada di dalam MARPOL baik annex I, II, maupun annex III, IV, V, dan VI yang diratifikasi lewat Perpres No. 29 tahun 2013.

Kebanyakan kapal yang melintasi perairan Indonesia dengan sengaja mematikan transmisi VMS mereka agar kegiatan operasional mereka tidak dapat dipantau oleh otoritas kelautan Indonesia yang akhirnya meningkatkan kemungkinan untuk kapal-kapal tersebut melakukan kegiatan pencucian kapal secara ilegal maupun dumping yang mengakibatkan pencemaran lingkungan di Selat Malaka. Pencemaran laut akibat proses pembuangan air balas, air cucian kapal, maupun limbah hasil operasional kapal secara ilegal seharusnya dapat dicegah dengan memberikan fasilitas lokasi transit maupun pencucian kapal yang memiliki teknologi yang mampu memfasilitasi kegiatan pencucian kapal serta pembuangan limbah yang ada di 
sekitar kawasan Selat Malaka.

Kurangnya pengawasan dan fasilitas lokasi pencucian kapal yang ada di kawasan Selat Malaka serta adanya aturan dari MPA Singapura yang ketat dan tingginya biaya serta sanksi jika melanggar mendorong para oknum melakukan tindakan pencemaran lingkungan di Selat Malaka (Gunadharma, 2019). Pengenaan sanksi pidana dalam pelanggaran terkait pidana lingkungan hidup masih memperhatikan asas ultimum remendium. Asas ultimum remendium adalah asas di dalam hukum pidana Indonesia yang mengatakan bahwa hukum pidana hendaklah dijadikan upaya terakhir dalam hal penegakan hukum. Oknum kapal yang tertangkap melakukan pencemaran lingkungan hanya diberikan sanksi berupa teguran.

Hal ini mengakibatkan para oknum kapal menganggap otoritas laut Indonesia lemah. Minimnya pengawasan dan pengecekan terhadap setiap kapal yang berlayar di kawasan Selat Malaka dan kegiatan operasional yang dilakukan kapal-kapal tersebut serta kecilnya hukuman yang diberikan kepada oknum yang tertangkap melakukan pelanggaran hukum memberikan dorongan kepada oknum kapal melakukan kegiatan pencucian kapal secara ilegal sebelum memasuki wilayah Singapura yang memiliki aturan ketat dalam hal pengecekan kebersihan kapal.

Berdasarkan penelitian ini, maka peneliti untuk memberikan rekomendasi bagi Pemerintah Indonesia untuk membangun lokasi transit di kawasan Selat Malaka yang memiliki fasilitas serta teknologi yang memadai agar setiap kapal yang melintasi kawasan tersebut dapat melakukan kegiatan pencucian kapal maupun pembuangan limbah sisa operasionalnya. Lokasi transit yang dapat direkomendasikan adalah Pulau Nipa. Pulau Nipa terletak di Selat Malaka dengan luas $+3600 \mathrm{~km} 2$.

Posisi Pulau Nipa sangat strategis dan berpotensi secara ekonomis karena terletak pada jalur lalu lintas kapal laut yang sangat padat. Pulau Nipa dapat dijadikan sebagai tempat transit kapal atau zona labuh jangkar sementara bagi kapal - kapal yang melintasi Selat Malaka. Reklamasi serta pengembangan wilayah Pulau Nipa yang telah dilakukan dapat membuka potensi pemanfaatan lebih lanjut yang dapat memberikan manfaat ekonomis dan lingkungan.

\section{Kesimpulan dan Rekomendasi}

Kerjasama antara pemerintah pusat dan daerah serta bantuan dari negara sahabat berperan penting di dalam melindungi ekosistem di Selat Malaka. Pemerintah pusat lewat sinergi eksekutif dan legislatif harus dapat mendorong komitmen bersama dari setiap organ politik Indonesia agar dapat mencapai kepentingan bersama yang dapat dirasakan oleh setiap masyarakat. Permasalahan lingkungan terkait pencemaran laut sangat mengancam ekosistem laut Indonesia dengan seluruh kekayaan sumber daya alam yang ada di kawasan Selat Malaka.

Sumber daya alam yang seharusnya dapat dinikmati oleh setiap masyarakat Indonesia bisa terancam akibat rusaknya ekosistem laut. Pemerintah Indonesia belum melakukan pengawasan yang maksimal terhadap lalu lintas kapal serta kegiatan operasional kapal-kapal tersebut yang dapat mengakibatkan pencemaran lingkungan.

Pemanfaatan Pulau Nipa sebagai lokasi transit kapal dapat mengatasi permasalahan lingkungan laut akibat tidak adanya lokasi khusus dimana kapal-kapal tersebut dapat melakukan kegiatan pencucian kapal dan tangki. Zona labuh jangkar yang di bangun di Pulau Nipa memerlukan fasilitas khusus agar dapat mencegah potensi pencemaran, dan kontrol terhadap kegiatan operasional kapal seperti pencucian kapal yang dapat menghasilkan pendapatan daerah. Dengan dibuatnya zona labuh jangkar dimana kapal dapat melakukan transit sekaligus pencucian kapal dan tanki sebelum melanjutkan pelayaran maupun memasuki wilayah Singapura, pencucian kapal secara illegal dikawasan Selat Malaka dapat dikurangi. Selain manfaat terhadap lingkungan, manfaat ekonomis dan strategis juga akan didapatkan 
dengan adanya pemanfaatan kawasan Pulau Nipa. 


\section{DAFTAR PUSTAKA}

\section{Buku}

Eide, Erling, Jorgen Aasness, and Terje Skjerpen. 1994. Economics of Crime: Deterrence and the Rational Offender. Amsterdam: North-Holland, 263-310.

Cote, Suzette. 2002. Criminological Theories: Bridging the Past to the Future. Thousand Oaks, CA: Sage Publications, hal. 285.

Till, Geoffrey. 2009. Seapower: A Guide for the Twenty-First Century, Second Edition. Seconded. New York: Routledge, 20-23.

\section{Wawancara}

Wawancara dengan Dr. Budhi Gunadharma Peneliti Pusat Riset Kelautan, pada tanggal 30 Agustus 2019 di Kementerian Luar Negeri, Pejambon, Jakarta.

Wawancara dengan Ir. M. Saefudin M.Si Ahli Madya Pengelola Ekosistem Laut dan Pesisir (PELP) Direktorat Konservasi dan Keanekaragaman Hayati Laut (KKHL) Direktorat Jendral Pengelolaan Ruang Laut (PRL), pada tanggal 30 Agustus 2019 di Kementerian Luar Negeri, Pejambon, Jakarta.

\section{Dokumen}

Convention on the Prevention of Marine Pollution by Dumping of Wastes and Other Matter 1972 (London Dumping Convention).

EAMF workshop Silient Points and Recommendation, Jakarta 29-30 Agustus 2019 International Organization Organization, 1988, Manual on Oil Pollution, Section II Contingency Planning, London, IMO, hal.2

MPA Singapore. Post Marine Circular: Procedures to Control Tank Cleaning and Disposal of Sludge And Slop. Port Marine Circular, 2018

Peraturan Mentri Perhubungan No. 29 Tahun 2014, Tentang Pencemaran Lingkungan Maritim

Undang-Undang No. 32 Tahun 2009, Tentang Perlindungan dan Pengelolaan Lingkungan Hidup.

\section{Jurnal}

Becker, Gary S. 1968. "Crime and Punishment: An Economic Approach.” Journal of Political Economy 78:169-217. https://olis.leg.state.or.us/liz/2017R1/Downloads/CommitteeMeetingDocument/12 503628

Explaining the International Environmental Cooperation of Democratic Countrie, CSD. Working Papers. August 1, 2001. pp. 1-19. hal.3 https://escholarship.org/uc/item/0gn942xm

Mendes, Silvia M. "Certainty, Severity, and Their Relative Deterrent Effects: Questioning the Implications of the Role of Risk in Criminal Deterrence Policy." The Policy Studies 
Journal 32, no. 1 (2004). hal59.

https://onlinelibrary.wiley.com/doi/abs/10.1111/j.0190-292X.2004.00053.x.

Moosa, Kasim. "Control of Marine Pollution in The Straits of Malacca and Singapore:

Modalities for International Cooperation." Singapore Journal of International \&

Comparative Law, 1998, 454.

Satz, Debra, and John Ferejohn. "Rational Choice and Social Theory." Journal of Philosophy

91, no. 2 (February 1994): 71-87. http://www.jstor.org/stable/2940928

Thambipilai \& Saravamuttu. ASEAN and The Law of SEA. Institute of Southeast Asia Studies, Singapore.tahun 1985.hal.8.

\section{Website}

Balai Pengelolaan Sumber daya Pesisir dan Laut Padang. 2018. "Resume Habitat Dugong (Duyung) di Pulau Bintan Kepulauan Riau”. Diakses pada tanggal 16 Oktober 2019. http://bpsplpadang.kkp.go.id/pubs/uploads/files/Resume\%20Habitat\%20Dugong\%20d \%20Pulau\% 20Bintan\%20Kepulauan\%20Riau.pdf

International Marine Organization. 2019. "Carriage of Chemicals by Ship". Diakses pada 20 Oktober 2019.

http://www.imo.org/en/OurWork/Environment/PollutionPrevention/ChemicalPoll ution/Pages/Default.aspx

International Maritime Organization. Ballast Water Management. Diakses pada tanggal 16 Oktober 2019.

http://www.imo.org/en/OurWork/Environment/BallastWaterManagement/Pag es/Default.aspx

Internasional Sindo News. "Jalur transportasi Air Paling Penting di Dunia". Diakses pada tanggal 16 Oktober 2019.

https://international.sindonews.com/read/1289403/45/jalurtransportasi-air-palingpenting-di-dunia-1520944003.

Kementerian Kelautan dan Perikanan. 2018. "Siaran Pers: Refleksi 2017 dan Outlook 2018 Membangun dan Menjaga Ekosistem Laut Indonesia.” Diakses pada tanggal 16 Oktober 2019. https://kkp.go.id/djprl/artikel/2798-refleksi-2017-dan-outlook-2018membangun-dan-menjaga-ekosistem-laut-indonesia-bersama-ditjenpengelolaanruang-laut.

Laporan Kunjungan Kerja Spesifik Komisi VII DPR RI untuk Peninjauan Pengloahan Limbah B3 di Kota Batam. 2019. "Masa Persidangan II 2018-2019.” Diakses pada 17 Oktober 2019. http://www.dpr.go.id/dokakd/dokumen/K7-Laporan-KunspekPanjaLimbah-dan-Lingkungan-ke- Batam-1547804641.pdf

LIPI. Monitoring Kesehatan Terumbu Karang dan Ekosistem Terkait di Kabupaten Bintan. Diakses pada tanggal 16 Oktober 2019. http://coremap.oseanografi.lipi.go.id/berita/1153.

International Marine Organization. "Marine Environment." Diakses pada 20 Oktober 2019 http://www.imo.org/en/OurWork/Environment/Pages/Default.aspx. "MARPOL Annex 1 -

International Marine Organization. "Prevention of Pollution by Oil." Diakses pada 20 Oktober 2019 http://www.imo.org/en/OurWork/Environment/PollutionPrevention/OilPollution/ Pages/Default.aspx. 
BAKAMLA. "Perjanjian Internasional yang telah Diratifikasi oleh Pemerintah Indonesia." Diakses pada 20 Oktober 2019.

https://bakamla.go.id/style/peraturan/PerjanjianInternasional.pdf.

International Marine Organization. "Prevention of Pollution by Garbage from Ships." Diakses pada 20 Oktober 2019

http://www.imo.org/en/OurWork/Environment/PollutionPrevention/Garbage/Page s/Default.aspx.

International Marine Organization. "Revised Specific Guidelines For The Assessment Of Vessels,” Diakses pada 20 Oktober 2019.

http://www.imo.org/en/OurWork/Environment/LCLP/Publications/wag/Documen ts/2016\%20Rev\%20Specific\%20Guidelines\%20for\%20vessels.pdf\#search=vessel $\% 20$ waste

SK, Ishadi. 2018. "Selat Malaka Dan Potensi Industri Bioenergi Indonesia." Diakses pada 20 Oktober 2019. https://news.detik.com/kolom/d-4223947/selat-malaka-dan-potensiindustribioenergi-indonesia 